\title{
Women, work and recession: the other face of unemployment
}

\section{Roberta Hill*}

In analysing women's economic role in a recession; critics and proponents of the "reserve army of labour" theory usually focus on the phenomenon of female unemployment. This paper looks instead at the effects of a female labour reserve on those in employment during a recession. The work experiences of 22 clothing machinists are used to illustrate the argument that a reserve of labour is a competitive force which facilitates management strategies to counter declining profitability. It is argued that such strategies can be pursued particularly successfully with a female workforce.

\section{Introduction}

The characterisation of women as a reserve army of labour has gained wide currency among feminists and writers of the Left. ${ }^{1}$ Proponents of this view argue that women, particularly those who are married, have been used as a convenient reserve of labour to be drawn into the workforce during an expansionary stage of an economic cycle, and to be disposed of when production contracts. For example, Owen $(1978$, p.26), has written that

Women have long been regarded as a reserve army which can be called upon in times of war or when a shortage of male labour threatens to push up rates of pay - and then relegated to unpaid domestic labour when the economy requires it.

Similarly, Adamson et al. (1976, p.16) maintain that women exist for capital,

as a cheap, unorganised source of labour. They can be called upon to augment the industrial reserve army, available to be drawn into or thrown out of employment according to the needs of capital accumulation at any particular time ... They are available at home to be drawn into production when necessary and can be thrown back into the home when accumulation stagnates.

Milkman (1976) and Gardiner (1975-1976), on the other hand, reject the view that women, as a distinct social grouping, can be discharged from employment during economic crises. Milkman (1976, p.75) has argued that although the reserve army concept is useful for analysing the entrance of women into the paid workforce over the long-term, it does not "tell us very much about their economic roles in a period of crisis". She points out that since the sexual division of labour among occupations creates an inflexibility in the

* Postgraduate student, Department of Sociology, University of Canterbury. The author wishes to thank Dr Rob Steven of the Political Science Department, University of Canterbury, for his untiring enthusiasm, and the hours he spent, in supervising the M.A. work from which the paper has been drawn, Rosemary Novitz for her guidance in the role of assistant supervisor, and Rosemary and Bob Gidlow for their helpful and constructive criticisms of this paper. She also thanks Peter Conway and other officials from the Canterbury (etc.) Clothing Workers' Union for their willing assistance.

1 See Milkman (1976, p.75), Adamson (1976, p.16), Beechey (1977, pp.56-58) and Owen (1978, p.26). 
structure of the labour market, women cannot be expelled from the workforce in the manner suggested by the theory. She goes on to argue instead (Milkman, 1976, p.75) that in an economic crisis it might be women's work in the home, rather than their labourmarket participation, which is "forced to take up the slack". In analysing women's employment in Britain between 1966 and 1974, Gardiner (1975-1976) found that the proportion of women among total employees actually rose during this period of economic contraction, and that women who were discharged from employment in manufacturing were being absorbed into the services sector rather than leaving the workforce altogether. She concludes, therefore, that in these years, women did not act as an industrial reserve army. ${ }^{2}$

More recently, Anthias (1980) discounts the explanatory potential of the classical form of the reserve army theory when applied to women's employment. She argues (1980, p.50) among other things, that the concept

refers to the role of "unemployment" within the abstract capitalist mode, whereas the main problematic concerning women's employment is its increase and the particular forms that it takes.

The problem with both the proponents and the critics of the concept in its application to women is that, since they tend to focus on only one of the different senses in which Marx used it, they fail to identify all the functions which a reserve army fulfils. Female unemployment is seen only in terms of a total discharge from the workforce, and the emphasis on job insecurity obscures the importance of the reserve army as a force which depresses wage-levels during economic recession. Those writers who have discussed women's role in keeping wages down have tended to concentrate on the contribution made by their domestic rather than their wage labour. ${ }^{3}$ For these different reasons, analyses and criticisms of the concept in its application to women's employment have at best been only partial. $^{4}$

\section{Marx's Use of the Term}

Marx (1975, pp. 628-645) employed the concept of an "industrial reserve army" in Capital to show how labour was used in the process of capital accumulation. However, his analysis was not worked out in detail, and he never clearly distinguished the different senses in which he used the term.

In the first place, he spoke of different types of active reserve army labour required for capital accumulation. One group of these comprised floating workers who would move from job to job as labour was used and discarded by different capitals. The other, latent workers, were drawn into employment when an absolute increase in the size of the working population was required for expanding industries or for new branches of production.

Secondly, Marx used the concept to describe the forms of labour generated, or made unemployed, by the process of capital accumulation. These were the floating, latent and stagnant pools of unemployed. The floating pool was created in the urban centres of industry when technological developments replaced labour with new machines. The latent pool, Marx argued, was the result of the introduction of capitalist technology into agricultural production in the rural areas. Subsistence producers in these areas formed a latent pool, because unlike the floating workers, they could not be immediately absorbed into capitalist production, although their decreasing ability to subsist on the land made them potentially easy to absorb should capital require them. The stagnant pool became unemployed for very long periods, and was generated by the periodic long-term tendency for the rate of profit to fall.

2 Gardiner (1975-1976, p.13) does analyse how high rates of redundancy affect women's pay and other working conditions, but she does not attempt to do so using the reserve army concept.

3 A notable exception, however, is the analysis by Beechey (1977).

4 Beechey (1977) has also criticised Milkman and Gardiner for the same reason. 
Thirdly, in Marx's analysis, the term reserve army also referred to an abstract law of capital accumulation. ${ }^{5}$ This "law" suggested that the reserve army acted as a "lever" of capital accumulation, because a pool of unemployed was a competitive force within the working class, and prevented those in employment from agitating for higher wages (Marx, 1975 , p.632). Through its effect on the value of labour power, the reserve army was therefore a necessary condition or requirement of capital accumulation.

Elsewhere ${ }^{6}$ I have attempted to show that, to understand how, and to what extent, female workers might be described as functioning in any of these different ways, it is first necessary to develop a precise theory of the reserve army and analyse how it serves and is created by the process of capital accumulation.

This paper has a more limited brief. It addresses the issue of whether the theory is at all useful in explaining women's role in paid employment during economic recession. As argued above, critics of the theory (like its proponents) focus on the phenomenon of unemployment. This emphasis obscures the role played by a labour reserve acting, in the way Marx suggests, as a competitive force for those still in employment in a recession. This paper uses qualitative data obtained from in-depth interviews to illustrate one way in which the reserve army theory can be used to analyse women's work in a recession. The data have been drawn from a study ${ }^{7}$ of 22 clothing workers made redundant in 1978 from Carters, ${ }^{8}$ a Christchurch clothing factory.

In the first section of the paper, the New Zealand clothing industry and the workings of the bonus system within clothing factories, are briefly discussed. It is argued that, during periods of high unemployment, the existence of a pool of unemployed female workers tends to facilitate employers' attempts, using the bonus system, to intensify employees' work ${ }^{9}$ to counter declining profitability. The next section gives examples of other strategies, also based on the bonus system, which are used during economic crisis to cut the real wages of staff and lay off the least productive workers ${ }^{10}$ without provoking effective union action. The concluding section shows that, while all employees are vulnerable to such strategies, female workers tend to comply with methods for achieving these goals which are less likely to be tolerated by men.

It is the argument of this paper that, although the particular strategies used by employers to maximise profitability are probably peculiar to the clothing industry, a similar process of work intensification and cost cutting could occur when semi-skilled female workers are employed in other industries with declining profits.

\section{The New Zealand Clothing Industry}

The clothing industry in New Zealand has a predominantly female workforce. In most factories and work-rooms the manager is a male, and men are more likely to work as designers, pressers, cutters and warehouse assistants, but the machinists, supervisors and examiners are almost always women. For example, at the time of the study, about $85 \%$ of the Canterbury (etc.) Clothing Workers Union were women, and only two of the 3,000 members were male machinists. ${ }^{11}$

5 This dinstinction was noted by Beechey $(1977$, p. 64$)$ in a footnote to her article.

6 See Hill (1979).

7 See Appendix.

8 Like all the names which refer to the interviewed women or to the factories in which they worked, this is a pseudonym.

9 and 10 I have avoided using the corresponding Marxian concepts of absolute and relative surplus value respectively to simplify the paper.

11 Information provided by a Union official. 
Butterworth $(1978$, p.11) has characterised the work done by many women in New Zealand in the following way:

the work-places are widely dispersed: the work is in small units of employment in many instances. It is subject to cyclical and seasonal fluctuations; it is generally low-skill to unskilled...

Commenting that the sectors of industry involved are often vulnerable to competition, she cites garment manufacture as one example. According to Butterworth, the small-unit enterprises of such industries "are under-capitalised, and have perennial cash-flow problems" (1978, p.11).

The work process in the clothing industry varies according to the nature of the product and the level of technology employed. In the large factories with modern technology, the production process is divided into numerous separate operations. Each operation is performed by different machinists using a variety of machines. For example, one Christchurch clothing factory which manufactures jeans has 28 different machines for 38 stages of the work process. One of these machines is a "bar tacker". The woman who operates it will attach five belt loops to each pair of partly-completed jeans with a bar tack (or small row of stitching) at the top and bottom to form and hold the loop. At the same time, she will sew two bar tacks at the bottom of the fly of the jeans and one on each corner of the four pockets -20 bar tacks in all. That operation will be repeated daily by the same machinist on hundreds of pairs of jeans. This work is referred to in the clothing trade as "production" or "piece work".

The medium-sized factories which make a variety of men's or women's clothes may divide up the work process so that the younger and inexperienced machinists are assigned to piece work. They will, for example, sew the fob pockets of men's trousers and shorts, as well as belts or collars for blouses and dresses. These pieces will then be attached to the garment by the experienced machinists, who are responsible for joining up the main pieces. Clothing workers refer to this as "making the whole garment". This work is done by safety-stitch machinists, overlockers or straight sewers. The work might then be finished off by a machinist operating a blind hemmer. Work on the hemmer is again considered piece work.

In the smallest factories or work-rooms, which tend to manufacture higher-priced "quality" clothes, machinists are usually responsible for making up virtually the entire garment. Typically, the workplace is a fashion boutique or small tailoring firm.

A machinist making the whole garment, such as a woman's coat or man's suit, performs skilled work requiring several years' training and work experience. However, the demand for such skill declines as the production process is divided up, or "de-skilled". Many machinists in the jeans factory, for example, needed only to hold the fabric against a metal guide, move a lever by knee, foot or hand, and the machine automatically completed the appropriate operation.

\section{The Bonus System}

The clothing trade is labour-intensive, technologically "backward", and vulnerable to competition. Although some productivity gains can be made by increased investment in technology, competition among firms depends heavily on intensifying the labour process and lowering labour costs. Therefore falling profitability can be countered, in the short term, first, by increasing the intensity of work which raises output per hour. Strategies to achieve this include (1) basing wages on output (or piece-wages) and (2) strict supervision and discipline. Second, wage costs can be cut by resisting wage demands and by laying-off the least productive workers. The greatest potential for pursuing these strategies in the clothing industry lies in the bonus system. 
Clothing workers are paid according to the New Zealand Combined Apparel and Related Trades Award. Under this Award they get a guaranteed minimum weekly wage. However, the majority of factories operate some form of individual bonus system under which machinists can increase their earnings by increasing the rate at which they work. "Times" or prices are allotted by the employer to particular operations or tasks in the work process. For example, a machinist may be given four minutes to join four panels of a skirt and overlock the hem. If she can complete the task in three minutes she will have made one minute bonus. If she maintains this speed she will have accumulated five minutes' bonus in one hour, and 40 minutes' by the end of an eight-hour day. At the rate of four cents per bonus minute, she could increase her day's wages by $\$ 1.60 .^{12}$ The bonus system is also calculated on the same principle, according to a price allotted a "whole" garment, or some part of it. Assuming a machinist is given a price of 16 cents for a particular task, and her weekly wage is $\$ 80.00$, she estimates that she will need to complete an average of 100 of these tasks a day to "make her wages". To make one's wages actually means to complete the total amount of work management believes can be done in a week. (The weekly minimum wage is divided by the number of estimated individual tasks, each of which then has a money value.) A machinist is then paid a bonus for any work over and above the minimum amount. However, even when a machinist fails to make her wages in any one week she must still be paid the award rate.

Ostensibly, a bonus is paid as a reward for the more highly-skilled employees, and for those who are prepared to work hard. Times for each task represent employers' expectations of a "reasonable" speed of work, and what is completed in less time is paid a bonus. This method of wage payment increases output in several ways.

The possibility of making a bonus spurs machinists into working faster. Although employers must pay out more in wages, the increased output more than compensates. The bonus system also encourages competition between the women who pace each other sometimes in a spirit of fun, but also out of jealousy.

Caroline, for example, recalled how, as an overlocker at Carters,

we had to make nearly $\$ 20$ a day. So Jennifer [the overlocker sitting beside her] would set herself a target of $\$ 30$. I would try and make $\$ 25$ and she used to encourage me. "How much have you done?" So I used to work it out. "Oh, come on you've got to go a bit faster than that!" So I'd get stuck into it again. Go $\operatorname{mad}$...

Jessie, the 69-year-old machinist, spoke of "jealousies" among the girls at Carters, and then added,

You might find in every place that you work, there might be a bit of jealousy. Well you do find that everwhere. "Oh look what she's got. Make more money on that than what I've got."

The following incident demonstrates how such jealousy over wages serves to increase output. Jennifer was talking of the biggest bonus she had made in one week at Carters, $\$ 78$. On one day that week she had made up 111 pairs of women's trousers.

The ladies that used to do my same job just didn't believe I could put out so much work. [That day] I knew this lady was pacing me. So just to annoy her I decided to go a little bit faster, and was I buggered by the time the day was finished.

Later that day, Jennifer explained, questions were raised about the number she had done: 
The older lady had put word into the supervisor that I was putting down more than I'd done. The work had to be checked.

Q. Why do you think she did that?

A. It's really just jealousy. They can't put out what you can and when you go home with a big fat pay-packet and they go home with half that ... [jealousies arise.]

The amount of work and the time taken by each machinist is monitored weekly, ostensibly in order to calculate bonuses, but its effect is also to intensify the pressure to raise output. The actual details of how work-output is recorded varies from factory to factory. Typically, the women themselves note the price they are given when they are allocated a particular bundle of work. They divide their minimum weekly wage by five. This daily wage is then divided by the price given each particular piece in the bundle. From this the women can determine the number of pockets, belts or garments they are required to produce in eight hours to make the day's wage. The same principle applies when the calculation is based on time rather than on price. At the end of the day, the supervisor or boss also checks the work done by each machinist, and a record is kept for comparison. At the end of the week, machinists and management have a record of the amount of work that each woman has done, calculated in terms of the weekly wage. If a machinist makes $\$ 20$ over her wage, for example, she will be paid a $\$ 20$ bonus. If she is $\$ 20$ down, she must still be paid the award rate, but this "failure" has important implications as a potential means of increasing work speed.

First, to make their wages, machinists must work at a pace determined by the time or prices set by management, and most of the women seemed to accept them as a norm for "doing a fair day's work". Second, because the women's work is recorded, a boss or supervisor knows when any machinist is down on her wages. Being told that she is so many dollars down makes a machinist feel uncomfortable, guilty or resentful. She will try to avoid being placed in such a position again, and will attempt to increase her speed to complete the required output. Carters Clothing Factory, for example, made its machinists record the work they did each day in notebooks which were collected once a week. The following conversation with Judy illustrates how the notebook system worked.

There was the big worry on the Tuesday. They used to collect your books in and if you didn't make your time they used to come out and give you a little talking to.

Q. Did they?

A. Well, if you were too far down (PAUSE) see they would work it out, if you were $\$ 10$ down they'd write it "Minus $\$ 10$ ". Mrs Carter would write it in. And they would not write when you made a bonus. . .

Q. What did it make you feel like?

A. Very guilty, because you see they were paying you a full wage whether. you were $\$ 20$ down, and they paid you that, and they obviously made you feel it by putting this in your book.

Later in the interview Judy referred again to the notebooks:

Those books they kept. It was so tight the system there. They would count (PAUSE) you'd write it in your book, then they would count it, almost calling you a liar, then would write it down themselves and check that off with the other, one. They had a big card on the office wall on who made it [their wage] afid who didn't make it. We weren't never allowed to see it, though when you went in the office the odd time you used to see it. They used to check up on everyone. 
As a complement to the bonus system as well as to ensure its proper functioning, most factories have some form of direct supervision on the shop floor. Factories with a staff of around 30 tend to have one female supervisor and her assistant, while the larger factories will have several female supervisors. In smaller ones and work-rooms, the boss may directly supervise the work process. Supervisory staff are concerned with allocating work to different machinists, assisting them when they are having difficulties, and generally keeping up the flow of work round the factory floor. They also check that the women are not wasting unnecessary time chatting, but are working at a steady pace. Supervisors or bosses also clock machinists with stop-watches when setting times for different tasks. They may even time various machinists at random as a check on their speed.

\section{Limits to the Bonus System}

Although the bonus system provides a variety of mechanisms to intensify the machinists' work and increase output, there are limits to its ability to do this. Union representatives can be called in if the price or time for any task is cut, and, more importantly, machinists will leave for easier jobs if pushed too hard. Factories gain reputations for being too tough, and clothing workers quickly learn through an informal social network which ones they should avoid. Particularly in boom periods when labour is likely to be scarce, these limits can be very real.

However, if a recession hits the industry, ${ }^{13}$ the least competitive firms may have to lay off workers to cut labour costs, and some factories will close down, laying off large numbers of workers. If the recession becomes more general, and widespread unemployment occurs, a reserve pool of unemployed women will be available to fill the unskilled and semi-skilled jobs in the remaining clothing firms, as well as in other industries. In this situation, a machinist is much less likely to leave her job. Particular forms of work intensification can therefore occur which overcome some of the limits usually operating on the bonus system. Seventeen of the machinists volunteered information that suggested, explicitly or implicitly, marked variations in the pace of work they had each experienced in their various jobs, and these variations correlated broadly with references they made to changing economic circumstances within the firm and in the industry generally. ${ }^{14}$

\section{Stretching the Limits}

\section{Cutting 'Times' and Hours of Work}

Theoretically, an employer cannot cut the times allocated to the specified operations in the manufacture of a particular style of garment. However, times can be manipulated in such a way as to do just this. Three different strategies were referred to by the women.

The first involves changing the style of a garment slightly and then giving it a lower price. During the interviews, reference was made a number of times to the way Carters had "cut their times towards the end". Olive explained how this had been done. She had been speaking about the unpleasant work atmosphere at Trufit Clothing Factory where she was currently working. She contrasted this with Carters, where "you could have a bit of a joke and that amongst yourselves. If the atmosphere's better". Then she added,

13 The extent of the recession in the clothing industry during the research period is suggested by the estimate that, in the Canterbury area, approximately 520 redundancies, and 32 closures of factories or work-rooms occurred in the period between January 1977 and January 1979.

14 There were exceptions. Francine, in referring to a factory from which she had been laid off, commented that "their times were a lot better than some of the other places". 
It was just when the atmosphere really started to change the girls thought " $\mathrm{Ah}$ well, to hell if they're going to drive us like this" (PAUSE)

Q. And did it change?

A. Yes, I think it did, and they had all this worry of the place falling through, and probably the girls suffered at their expense, but (PAUSE).

Q. What, they started to (PAUSE)?

A. Yes, put the screws on us and all that sort of thing. Before Christmas it started.

Q. Were you ever aware that they cut your times?

A. Oh yes, they did, but where we couldn't do anything about it was they changed the style a bit. To do mohair coats, $\$ 1.69$. Sometime after that we did a coat, $\$ 1.40$ something, only changed in the slightest way, and the price was lower, but we couldn't do a thing about that because that was a new style. It might have been a different pocket, (PAUSE)

Q. And the coat would take the same amount of time?

A. More or less the same sort of coat but just changed a little bit.

The following comment from Caroline also suggests the extent of the intensification of work in the factory at that time. Jennifer, the machinist to whom Caroline refers, was one of the fastest at Carters. (During her interview she had spoken of "nearly doubling her wages" on one or two occasions.)

All the old prices, every time we got a wage rise, they'd be stepped up so much percent. The things they'd been doing for years had a really good price on them. But as it got to the end the prices got lower and lower and it got harder and harder to make your wages, and even Jennifer sometimes couldn't make her wages, and sometimes you'd be $\$ 20$ down ...

Similar pressures to increase work output were employed in other firms in financial difficulties. Sandra, for example, prefaced her answer to a question about what she had done in her second job with the comment, "It was a leather place. They've gone down" (she meant the work-room had closed since she was working there). When asked why she had left, she replied:

They made you work really fast. You had to do your work and that was it. Times [set by the boss] were hard. It was difficult.

Using the fastest machinist as a basis for setting times was the second way in which the pace of work could be intensified. Three of the women volunteered information about this. As Cheryl explained it,

all you needed was one person able to make the time and the union couldn't do a thing about it...

I've talked to girls at other places and a lot of them comment how it's not fair that they take the times from the fastest machinist or one of the fastest there.

Then she added, matter-of-factly, "well, they're going to make their money if they can get everyone up to that standard."

The third strategy for manipulating times was to cut the hours of work while still expecting the machinists to produce the same output. Here Lisa is speaking about Trimwear Garments, a Christchurch clothing factory of similar size to Carters.

He [ the manager] cut our hours down and expected us to do 40 hours' work when we were only getting paid for 36 hours, and some of the girls (PAUSE) well, I could get nearly half of it out. I got my wage out but he expected us to get a bonus out and we couldn't, we just couldn't, not with 36 hours; and we had to do 14 coats a day. In one part we had to do 24 ... He expected us to do 24 coats a day. Half of us couldn't even do 12 . 
Later in the interview she noted that "a lot of talk's gone round that Trimwear's is going to close down in three months".

A number of the women interviewed seemed to lack confidence in assessing their own abilities as machinists. At one level, they could see that their failure to make their-wages was the result of a reduction in the times they were given, and, like Caroline (referred to above) they would point out that even the fastest machinists had difficulty making their wages. Nevertheless, they still talked about feeling awfully guilty when they were down on their wages. The following comment illustrates how the women's lack of confidence was reinforced by their fear of losing their jobs. Here Robyn reveals the ambivalence she felt about being down in her wage.

Say I was $\$ 5$ down. Jeanette [the supervisor] would just go past and say "Oh, you're down $\$ 5$ this week Robyn", and walk off. But you never took it seriously. You'd know in yourself if you were doing alright. But at the same time, sometimes you don't know 'cos we'd get little wee talks. That was that times (economic times) were getting hard. That was about six months before we were laid off.

Q. What would Jeanette say?

A. "If you don't make your pay you'll have to go, that's all there is to it. There's no hard feelings or anything like that." Some did go.

\section{Intensifying Supervision and Discipline}

It has been argued that different strategies are used during periods of declining profitability to cut the times given machinists to complete specific tasks. Because of the importance women attach to making their wages, and the effects of a bonus in increasing work speed, their output per hour is increased accordingly. The other way in which the output of machinists can be raised is through stricter supervision and work discipline.

Closer supervision of the job itself can raise productivity. Women who were fast machinists spoke of being "pushed" to keep up their output. Cheryl, for example, was speaking of the new boss who took over three months before she left Mitchells.

When I was on the blind-hemmer he'd come up to us and say, "well I want you to make $\$ 6$ bonus tomorrow," if you made 5 the day before. Kind of pushed you a bit (PAUSE)

Q. Did he?

A. As though to push us. Well, they were making good overheads on our bonus you see so (BREAK) oh it's good for him if we (BREAK) but I used to get so tired.

In speaking of factories where they felt pressured, women characteristically made reference to "little chats" from the boss or supervisor about the need to increase output because "things were tough". For example, Ida commented that in the months before they were made redundant from Carters,

Jeanette [the supervisor] used to come and say "You girls have got to hurry. They're going crook about you girls not working harder." And "You'll all be without jobs if you don't work a bit harder. Cut out talking and work harder."

Tight discipline during work hours also increases output. Eight of the women who had worked during the recession in seven different factories volunteered explicit examples of extremely tight work-discipline. Three of these women left their jobs within a few days. The examples suggest that at a time of recession in the clothing industry, discipline in some factories can be extremely severe. However they do not reveal whether discipline intensified as a firm's economic circumstances worsened, although it seems reasonable to presume this. 
In the clothing industry, bosses or supervisors typically seem to control the amount of time women spend in talking and not working. What is significant from the interviews are the extraordinary lengths to which bosses in the seven different factories went to control time wasted not only in talking, but also in visits to the toilet. After leaving Carters, Clare went to a small factory, where the boss "was expecting more than twice the (normal) amount out of us", and she commented that

he'd watch you all the time. While I was in the toilet one time he came and turned the light off. He was trying to save every cent he could. The switch was out in the hallway and he turned it off. And he'd time you [going to the toilet]. To him that was lost time, lost minutes to him if we went to the toilet two or three times a day and take three or four minutes each time. It was really incredible.

The boss at Trimwear Garments where Lisa went after losing her job at Carters was more explicit. The following conversation was a response to a question about what she thought of machinists' wages compared with those of other workers. Lisa replied that the money at the jeans factory where she was then working was good, but it was too low at Trimwear's. She went on,

I reckon I should have got more money because you were getting pushed, and you were working as hard as you could to get their wage. Even if you went to the toilet the boss always had his eye on you to see how many times you went to the toilet, and I reckoned that was silly.

Q. Do you really think he watched how many times you went to the toilet?

A. He even told me. He come up to me and quite a few girls when we first started there, and he says "Don't go to the toilet too much." He says "You're only allowed to go in your breaks." That was his way.

Before you started work you had to go, then you had to go at morning tea, your lunch hour. Even though you didn't want to go you had to go. He says to me, "I watched one girl just yesterday and she went to the toilet eight times."

This is how Caroline spoke of the boss at Charltons, a small suburban clothing factory with a staff of 15. (At one stage later in the interview, she had commented, "of course, he was all going bankrupt. I think he's still going [in business], but he's still going bankrupt.") She had just been asked what her fifth job had been. She named the factory, and went on,

I was there getting on for two years, and oh, he was a pig, he really was! He used to take it in turns to pick on different girls each week.

Q. In what kind of way?

A. He used to go right up the stairs to his office and he had a little peep window up there and he used to watch, until they'd be working all morning, and then they'd stop for five minutes and say something to someone else and he'd come running down the stairs [the office was on a mezzanine floor above the machinists]. He'd come storming out and scream his head off at them for talking or he'd sneak up behind you, and he'd slam his hand down on the table and say [raised voice]: "How much have you done today?" Oh he was terrible.

\section{Reducing Wage Costs}

I have argued that firms with declining profits may attempt to stave off bankruptcy by intensifying work using a variety of different strategies based on the bonus system. Firms can also employ a number of methods to reduce wage costs. The interview data suggest that in a recession the wages of existing staff can sometimes be cut, and the least productive workers laid off, without always provoking effective counteraction by the union. 
Wages can be cut in three ways. The first relates to the piece-rates paid under a bonus system. As suggested earlier, prices on garments have to be increased the appropriate percentage with every wage-rise. Where a bonus is paid at the same hourly rate as wages, bonus payments will obviously rise by the same percentage. However, mention was made of a bonus system at Mitchell's which was based, not on the price of a garment, but on a "minutes system". Unlike other systems the women discussed, this one operates on a daily basis. Women are required to produce a specified amount of work each day. This amount is derived from calculations of the time management allots each task as a proportion of the 450 minutes a day which are needed to "make your wage".

Any machinist who produces more than the equivalent of 450 minutes in tasks or garments is paid a bonus at the rate of one cent a minute. The wage-rate is, however, just over five cents a minute. A wage rise which is not applied to bonus times (as in the case of Mitchell's) can therefore actually turn out to be a reduction in real earnings.

Jennifer's experience at Mitchell's Clothing Factory suggested two other methods by which wages can be cut. The way she describes and understands how this is done also provides an appropriate illustration of some of the complex processes which lie behind women's lack of resistance during periods of recession. These processes are summarised in the conclusion of the paper.

The first method relates to the payment of $\$ 4$ weekly as attendance money. Before getting the job, Jennifer had been told that this was paid to all those workers who turned up every day on time for work, and took no time off during that week. Jennifer soon discovered that she was not going to be paid this money, because the payment had now been suspended, and new workers would not receive it. In her seventh week there, the union representative had a discussion with about half of the staff. It was,

only the ones who got [attendance money] and I thought everyone got it. Well, the boss had put a plea across to the workers that "Mitchell's isn't doing so well at the moment and things are tough in the clothing trade, and women are getting made redundant, and would those who get attendance money, would you put up your hands and volunteer to give it up?" So what did they do? They all put their hands up except for two women. So, because those two women didn't the union was called in. And did he do his nut: the union bloke. [Contrary to what the boss had said] he said the firm we were working for was one of the safest jobs around because we have export, and the government subsidises them. So they had a secret ballot. Only those who got attendance money. They all decided they didn't want to give [it] up.

In this instance union action was effective in preventing a wage cut.

The second method concerns a seven percent cost-of-living adjustment to machinists' wages. A dispute arose over the basis on which part-time workers were to be paid bonuses. The seven percent went to all workers on the first $\$ 100$ of their wage. Full-time machinists at that stage were earning just over $\$ 100$ gross, and received the full $\$ 7$. The management at Mitchell's, however, paid part-time workers 7 percent on their weekly wage of $\$ 88$, but were not prepared to adjust their bonus earnings over that amount.

The women voted on the issue. Twelve were against the payment for the part-timers, 34 were for it. There was a meeting between the boss and the women, Jennifer said.

The boss said "those girls who were full-time that had nothing to do with them (the part-time workers). Why were they backing the others?" He got really wild. He'd done his block. He ranted and raved.

Q. Did the girls say anything?

A. The girls were so confused, they just didn't know what to think. Now, this is the stupid thing about it. Some of them were thinking they were going to lose their jobs. This is how really terrifying [sic] the women do get. I said, "You can't lose your job, not over a union matter." "Oh yes we can." I said, "you can't". 
Two days later we had another meeting. The boss, the union [representative], all in the room together. The boss put his point across, brought in about bonuses, and future pay increases. He really confused those girls' minds. And then we had a vote. [The union representative] said you vote for me or [she named the boss]. In other words, the union or the boss, and you know what 13 were with the union and 34 were against it. This is how (PAUSE) he really terrifies the girls.

Q. Just him, or is this fairly typical of the places you've been in before?

A. Oh, a lot of bosses do scare the girls, but he has his own way.

Q. Of those really terrified, was it the older ones, the younger ones, married women? Any particular group?

A. No it's just women. It's just a feeling that a man is talking over them. (PAUSE) That's the only way I can explain it. They were just scared because that's a man talking over them. He's the boss and he's got the say. Well, it's not always that way. But they just cannot see it. See, like when the union was there, one particular lady was agreeing with the union so much, then when the boss was talking she'd be agreeing with the boss. You know. And that just doesn't go down with me. They're just too scared to back each other.

I have shown from the interview data three ways in which wages could be cut when firms are seeking to reduce labour costs. As already pointed out, the union can intervene when times are directly cut. In the same way, if women are fired, they have a right to claim reinstatement, and the union can be called in. Furthermore, if retrenchment is necessary, then redundancy payments may have to be paid to those who are laid off. In practice, however, it seems that staff numbers can sometimes be reduced and both these consequences avoided.

During a recession when times or prices are manipulated, only the fastest machinists will be able to make their wages. The slower ones will be consistently down each week. A boss or supervisor can then "legitimately" claim that the slow machinist is not earning her wages and must go.

As I have shown earlier, since women tend to internalise the times as a norm for a fair day's wage, if they are down on their wages they feel guilty and worry about their failure. This feeling is heightened by remarks that are made to them about being "so many dollars down". Those who are fired are then unlikely to go to the union, even if they consider their dismissal unfair, because being fired is partly seen as a personal failure.

Two of the machinists had been fired from jobs they went into on leaving Carters. Naomi was told to leave Trimwear's after one week. The way she described being sacked shows how readily she submitted to dismissal, although she obviously considered she had been treated unfairly. She had just explained that the boss had come to her before work ended on Friday.

The way he went about it, giving you the sack! I mean, they could have given you a week's notice, or said, if you don't pick up in a week I'm afraid we'll have to let you go. But to give you two minutes' notice. That was a bit lousy that. It's just that I wasn't fast enough. Jeanette [supervisor at Carters] told me I'd got six months' [trial] to try to get up my quota. If he [Trimwear's boss] had given me even a month's trial, I reckon I'd have got the hang of it.

Naomi went on to say that other workers had told her quite a bit about the place.

He give others the push. It's a wonder they don't go to the union. But after I got it I just give up.

Q. Did you go to the union?

A. No. 
Q. Why?

A. Oh, I don't know, I just give up then. To be sacked, though, that was disgusting! In my books (PAUSE) that was disgusting, in my books to be sacked. I just couldn't hack it, just couldn't face being sacked. It's the first time I've been sacked. I've worked all my life. Never!

Q. You could go to the union?

A. Steve [her husband] reckons I could have got reinstated, but I said no. I'm giving it up. I just went to the pack after that. I just (PAUSE) being sacked (PAUSE) that was the most disgusting thing.

For Naomi, having a husband to support her was clearly also a factor in her compliance. She did not seek work again for over two months.

Robyn complied in a similar way. The following conversation with her also summarises reasons why women might submit more readily than men to lay-offs or firing. When she was fired in June from a clothing factory after four weeks' work Robyn was pregnant and knew she would be finishing anyway in December. In the interview she had just been asked if she had contacted the union after being laid off.

If I wasn't pregnant and I knew that I had to keep working for a period of time I would have thought about it, cos that's different (PAUSE). I mean, there are not that many clothing places left [because of factories closing] and it makes you think twice.

Like Naomi, Robyn was too slow, but, she explained, she "went slow at first to do a neat job. In a new job, you are slower, but you know you're going to speed up." She said that the factory "just wanted extra hard workers". She spoke of talks from the boss in which he said that "people have got to pull their weight on the machines (PAUSE) to keep the place going, cos sales are harder", and then commented,

But I'm a hard worker anyway. I used to work quite hard. I really tried, and my work's not scruffy. I just couldn't keep up with the (PAUSE) I couldn't produce what they wanted me individually to do.

At another stage in the interview she referred back to that job.

They didn't give me a chance. They said, if you don't get your time up you have to go. I more or less got told to go. I said, "I'll go anyway." That was embarrassing that part ...

His wife [who worked in the office] said, "Oh you've been good here, but you're not quite up to our standard." So I said, oh well, I'll make it easier, so I'll just leave, and that was that.

\section{Conclusion}

In the preceding discussion I have shown different ways in which limits to the bonus system can be stretched or overcome during a recession in the clothing industry. The discussion reveals the complex processes that appear to lie behind women's lack of resistance to mechanisms for intensifying work and cutting wage costs. Based on the interview data, it seems that women tend to comply with these mechanisms for either one, but more usually a combination, of four main reasons:

First, the existence of a labour reserve means women cannot readily find new jobs should they leave their present ones, and their fear is that they "will be sent down the road" if they resist management's demands. This is why they tend not to raise with their union such matters as time-cuts, excessive work discipline, or wage-cuts. 
Second, women are accustomed to complying with authority, particularly male authority..$^{15}$ At the same time, male employers are accustomed, in their domestic role as husbands, to exercising authority over women. Since women tend also to lack confidence and are unsure of their abilities, they are vulnerable to suggestions that their work is too slow.

Third, production under a bonus system tends to divide members of the female workforce against one another. This hinders them in developing any common interest they have as workers, and makes it hard for them to stick together on issues that individuals raise with the union.

Fourth, women in permanent relationships typically see their primary role as working in the home and caring for children, and this sexual division of labour can provide them with financial support from their husbands. Women might therefore submit more readily to wage-cuts and lay-offs when they define themselves as a "second-income earner", or when lay-offs occur early in pregnancy or coincide with the stage when they intended "to start a family".

There are a number of problems associated with using the reserve army of labour thesis to analyse women's employment, particularly during a recession. One major problem centres on the idea, suggested by the theory, that women (particularly married women) can be brought into the workforce and dispensed with as conditions of production change. A serious objection to this conceptualisation is that there is a sexual division of labour among occupations which creates an inflexibility in the labour market.

The argument of this paper has focused, instead, on what happens to the nature of the work women do in a recession when they face competition from a female labour reserve for a reduced number of jobs. It suggests that working women may intensify their workeffort and submit to wage-cuts because such management strategies can be pursued most successfully with a female workforce when unemployment is high.

I have illustrated the argument with reference to the particular work experiences of the 22 clothing workers studied. These illustrations reveal the pressures on women to comply. The argument does not preclude the possibility of women in the clothing industry developing effective worker organisation and taking collective action when they see their livelihood threatened. ${ }^{16}$ The Rixen clothing workers' protracted sit-in is an obvious example. Given the nature of the pressures faced by the women in the study however, research is needed to determine under what conditions women in such industries will be able, or prepared, to confront male employers in their collective interest.

\section{Appendix}

The argument of this paper was developed primarily from a study of the work experiences of 22 women made redundant from Carters Clothing Factory in 1978. In-depth tape-recorded interviews (ranging from $1 \frac{11}{2}$ to 3 hours in length) were conducted in the homes of each of the women. Between them they had held 112 machining jobs in more than 65 different clothing factories and work-rooms predominantly in Canterbury and Westland. Their ages ranged from 17 years to 69 , and 17 of the women were in stable relationships.

Carters began production in the early 'seventies with a staff of between 35 and 40 . This number had been reduced to about 28 by the time Carters, in serious financial difficulties, went into receivership. The Carters, who owned the factory, laid off the entire staff apart

15 The M.A. thesis from which this paper is drawn should be consulted for further evidence to support this claim, which is, however, consistent with the findings of research in the sociology of sex roles; for example, Novitz (1978).

16 See for example Conway (1979, pp.16-17). 
from a designer, a sample machinist, a cutter and two warehouse assistants. These employees continued to design, cut and make samples of garments for production in other factories. At the time of the study, Carters was one of 200-250 factories and work-rooms in the Canterbury, Westland, Marlborough and Nelson areas employing from one to 300 workers.

The research was conducted as part of an M.A. thesis, "Women, Capitalist Crisis, and the Reserve Army of Labour", completed at the University of Canterbury in 1979. I began with a structured interview schedule which entailed assumptions about female unemployment based on the reserve army of labour theory. As the study progressed it became obvious that, even at a time of high unemployment, these particular women had found other jobs and experienced little or no unemployment. The focus of the interviewing changed. Apart from those related to biographical details, standard questions were used only to determine what jobs the women had held, for how long, and why they had left them. Much of the data for the thesis comes from the women's responses to such general questions on their working lives. Detailed probing was undertaken only when issues were raised in the interview which seemed important to them. Chapter Two of the thesis should be consulted for further details of the methodology.

\section{References}

Adamson, O., C. Brown, J. Harrison and J. Price (1976) Women's oppression under capitalism Revolutionary communist (5):2-48.

Anthias, F. (1980) Women and the reserve army of labour: a critique of Veronica Beechey Capital \& class 10 (Spring):50-63.

Beechey, V. (1977) Some notes on female wage labour in capitalist production Capital \& class 3 (Autumn):45-66.

Breugel, I. (1979) Women as a reserve army of labour: a note on recent British experience Feminist review 3:12-23.

Butterworth, R. (1978) Women in the workforce New Zealand journal of industrial relations $3: 11-13$.

Conway, P. (1979) The extraction of relative and absolute surplus value in the clothing industry. Paper presented to Marxian Political Economy Conference, Wellington.

Gardiner, J. (1975-1976) Women and unemployment Red rag (10):12-15.

Hill, R. (1979) Women, capitalist crisis, and the reserve army of labour. M.A. Thesis, University of Canterbury.

Marx, K. (1975) Capital: A critique of political economy. Vol. 1: The process of capitalist production. New York: International.

Milkman, R. (1976) Women's work and economic crisis: some lessons of the Great Depression The review of radical political economics 8 (Spring):73-97.

Novitz, R. (1978) Marital and familial roles in New Zealand: the challenge of the Women's Liberation Movement. In P.G. Koopman-Boyden (ed.) Families in New Zealand society Wellington, Methuen.

Owen, M. (1978) Notions about the employment/unemployment of women Women and labour conference papers: 2 The experience of work Sydney, N.S.W.: 2434. 